\title{
Use of rocky intertidal habitats by juvenile pollock Pollachius virens
}

\author{
Robert W. Rangeley*, Donald L. Kramer \\ Department of Biology, McGill University, 1205 Docteur Penfield Avenue, Montreal, Quebec, Canada H3A 1B1
}

\begin{abstract}
We investigated patterns of distribution and foraging by young-of-the-year pollock Pollachius virens in the rocky intertidal zone. Pollock were sampled by beach seine in fucoid macroalgae and in open habitats at all stages of the tide, day and night throughout the summer. Their presence in shallow water at the high tidal stages indicated that at least part of the pollock population migrated across the full width of the intertidal zone $(150 \mathrm{~m})$ each tide. Densities in shallow water were much higher at low than at high tidal stages suggesting that a large influx of pollock moved in from the subtidal zone at low tidal stages and then dispersed into intertidal habitats at high tidial stages. There were few differences in pollock densities between algal and open habitats but abundances likely increased in the algal habitat at higher tıdal stages when changes in habitat availability are taken into account. Densities were higher at night and there was an order of magnitude decline in pollock densities from early to late summer. In another study we showed that piscivorous birds are a probable cause of pollock summer mortality. Pollock fed on invertebrates from intertidal algae relatively continuously. The tidal migrations of juvenile pollock observed in this study and their use of macroalgae as a foraging and possibly a refuging habitat strongly suggests that the rocky intertidal zone may be an important fish nursery area
\end{abstract}

KEY WORDS: Marine fish nursery - Rocky intertidal zone - Habitat selection - Pollachius virens . Pollock - Macroalgae Foraging $\cdot$ Gadidae Beach seine

\section{INTRODUCTION}

The importance of aquatic vegetation as a habitat for small fishes, particularly juvenile stages, has been demonstrated in numerous studies (see Heck \& Crowder 1991). In marine systems, studies have focussed on the importance of marsh grasses (e.g. Kneib 1984), seagrasses (e.g. Sogard 1992) and kelps (e.g. Holbrook \& Schmitt 1988). Fucoid macroalgae of the rocky intertidal zone may play a similar role, but the use of this habitat by fishes is poorly understood (Wheeler 1980, Gibson 1986, Rangeley 1994a). One of the important features of this habitat is that its availability to fishes changes with the tides. This effect is notable in the Bay of Fundy, Canada, which has an extremely large tidal range and a permanent cover of dense fucoid algae in

\footnotetext{
- Present address: Huntsman Marine Science Centre, St. Andrews, New Brunswick, Canada EOG 2 X0

E-mail: hunstman@nbnet.nb.ca
}

the rocky intertidal zone. These features create a dynamic environment where the availability of algal habitats to tidally migrating fishes can change from zero at low tide to hundreds of metres at high tide, only 6 h later.

Use of rocky intertidal zone habitats by juvenile pollock Pollachius virens was investigated in this study. Pollock is an important fisheries species common on both sides of the North Atlantic (Bigelow \& Schroeder 1953). In the northwest Atlantic, pollock spawn in the winter on the Scotian Shelf, off Cape Breton and in Massachusetts Bay (Scott \& Scott 1988). The larvae hatch from planktonic eggs in 6 to $9 \mathrm{~d}$ (Markle \& Frost 1985) at lengths of 3 to $4 \mathrm{~mm}$ (Fahay 1983) and have a pelagic residence time of at least 3 to 4 mo (Mayo et al. 1989). Juvenile pollock (age $0+$ ) then move into shallow intertidal and subtidal zones along the New England coast, the south shore of Nova Scotia and along the coasts on both sides of the outer Bay of Fundy (Bigelow \& Schroeder 1953, Steele 1963, Scott \& 
Scott 1988, Clay et al. 1989). Juvenile pollock appear in intertidal zone collections in early May at mean fork lengths of $3.7 \pm 0.04 \mathrm{~cm}$ (MacDonald et al. 1984, Ranglely \& Kramer unpubl.) and by late May they no longer occur in plankton samples (Marak \& Colton 1961). By October pollock attain mean lengths of $17.0 \pm$ $0.53 \mathrm{~cm}$ in their first year and mean lengths of $30.4 \pm$ $0.95 \mathrm{~cm}$ in their second year (Rangeley \& Kramer unpubl.) and then move offshore for their adult life (Steele 1963, Scott \& Scott 1988, Clay et al. 1989). Pollock rarely occupy tidepools (Moring 1990, authors' pers. obs.) and therefore leave the intertidal zone with each ebb tide. Thus, pollock are a promising species with which to investigate habitat use in the rocky intertidal zone.

In this study we determined the extent of intertidal zone migration and foraging by juvenile pollock in the rocky intertidal zone and assessed its importance as a juvenile nursery area. First, we examined the effects of changes in the tidal stage and diel and seasonal periods on pollock densities in shallow intertidal habitats. Second, we examined pollock stomach contents to determine the relative importance of intertidal habitats in contributing prey to pollock diets.

\section{METHODS}

Study area. This research was conducted in the outer Bay of Fundy in Passamaquoddy Bay, New Brunswick, Canada (Fig. 1). This region has semidiurnal tides with an average amplitude of $5.5 \mathrm{~m}$ (Thomas et al. 1983). The inshore summer water temperature range is 4 to $11^{\circ} \mathrm{C}$, and the average salinity is $32 \mathrm{ppt}$ (Trites \& Garrett 1983). Vigorous tidal mixing prevents extensive ice formation, which allows a permanent covering of fucoid macroalgae to exist on rocky shores (Thomas et al. 1983). The dominant fucoid is rockweed (also known as knotted wrack) Ascophyllum nodosum, which forms a dense canopy on sheltered shores, averaging 5 to $6 \mathrm{~kg} \mathrm{~m}^{-2}$ of dry biomass and with frond lengths ranging from 1 to $3 \mathrm{~m}$ (Keser et al. 1981, Vadas et al. 1990, Briand 1991).

The study was conducted in 4 coves roughly similar in size, topography and substrate (Fig. 1). The study sites ranged in area from 28908 to $37100 \mathrm{~m}^{2}$ Sampling was conducted over 6 tidal stages consisting of low tide [0 to $120 \mathrm{~cm}$ above chart datum (CD)], low-rising/ falling (121 to $320 \mathrm{~cm}$ above $C D$ ), high-rising/ falling ( 321 to $520 \mathrm{~cm}$ above $\mathrm{CD}$ ) and high tide (521 to $620 \mathrm{~cm}$ above $\mathrm{CD}$ ). The low intertidal $(0$ to $120 \mathrm{~cm}$ above $C D$ ) and subtidal zones consisted of mixed substrates of cobble, bedrock and mud and were devoid of large plants. Tide height was measured from tide markers located at our study sites. Macroalgae are

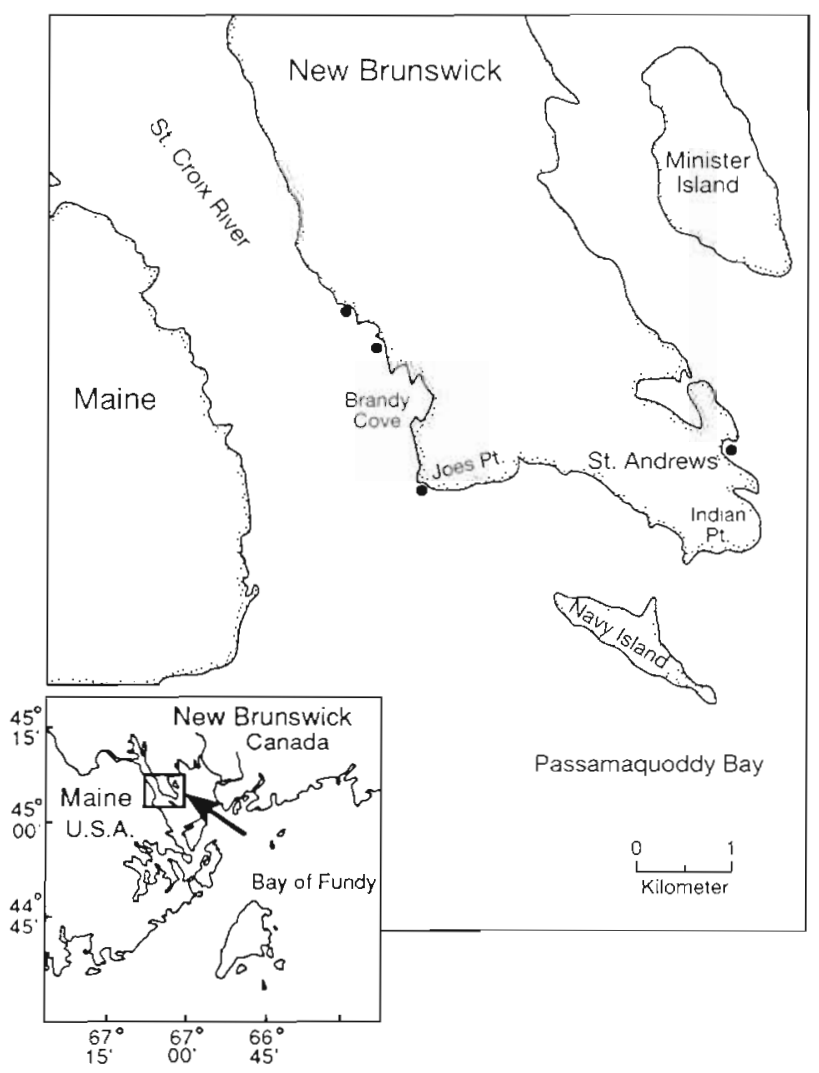

Fig. 1. Study sites in Passamaquoddy Bay, southwest New Brunswick, Canada

absent in the subtidal zone of this region, probably as a result of grazing by green sea urchin Strongylocentrotus droebachiensis (Thomas et al. 1983). Above the low intertidal zone were rock boulders and reefs which provided firm substrates for the holdfasts of large macroalgae. In addition, interspersed among the rocks, there were patches of mud and sand substrate which were open habitats lacking vegetation.

Pollock sampling. Juvenile pollock were sampled by beach seine from May 2 to August 16, 1989 and May 10 to August 23, 1990. The seine net measured $1.2 \times 10 \mathrm{~m}$, with a $6.35 \mathrm{~mm}$ stretched mesh with floats on the top line, a lead line on the bottom, and poles at each end. For each sample, 2 people hauled the seine through approximately $100 \mathrm{~m}^{2}$ of either algal or open habitat in a maximum depth of $1.2 \mathrm{~m}$. The sample area was estimated by pacing the required seining distance. For example, when the $10 \mathrm{~m}$ seine net was hauled fully extended, the sampling width was reduced to $8 \mathrm{~m}$, due to net curvature, and the required seining distance was then $12.5 \mathrm{~m}$. Seine hauls were conducted in each of the 4 sites during each of the 6 tidal stages 2 to 3 times a week. There was a minimum of 5 seine hauls on each site visit per tidal stage. Visits to each site were alter. nated so that no site was visited on consecutive tidal 
stages. There was a total of 1637 seine hauls of which 377 were at night. The criteria for day and night periods were based on sunrise/sunset tables supplied by the Canadian Atmospheric Environment Service. Preliminary sampling was conducted to perfect the technique on rocky shores and to verify that fish were not escaping the seine. Captures from each haul were immediately identified, counted and fixed in $10 \%$ formalin in seawater An incision was first made in the ventral body wall to allow rapid penetration of the formalin to the stomach contents. When more than 5 pollock were caught in a haul, they were kept alive in a pail or in a submerged pocket of the seine and a subsample of 5 was removed by dip net. Pollock were transferred to $50 \%$ isopropyl alcohol within $24 \mathrm{~h}$ of capture.

Fish were measured to $0.1 \mathrm{~cm} \mathrm{FL} \mathrm{(fork} \mathrm{length)} \mathrm{and}$ weighed to $1 \mathrm{mg}$ in the laboratory. Stomach contents were extracted, blotted to remove excess water, and weighed to $0.1 \mathrm{mg}$. Most prey were identified to species. The major prey groups were categorized into 3 habitat types: (1) algae, which included species typically attached to or strongly associated with macroalgae; (2) benthic, which included species from softsediment benthic habitats, usually mud infauna or epifauna; and (3) pelagic, which included those known to inhabit the water column. Authorities for prey identification and habitat classification were Sars (1890), Gosner (1971), Bousfield (1973), Brinkhurst et al. (1975), Cheng (1976), Linkletter et al. (1977), Smith (1977), Hayward (1980) and Coffman \& Ferrington (1984).

We used 3 measures of diet composition. The frequency of occurrence of each food type was the proportion of pollock which contained that food type. This measured the uniformity with which the sampled pollock population included the food item in their diet. The prey composition was the average number of food items sampled from pollock stomachs that were consumed in each of the 3 habitats. And finally, the percent composition was the average volume of food that was consumed in each of the 3 habitats. Food volume was estimated visually, using a binocular microscope, after sorting of the contents of each individual's stomach into food types over a grid of $1 \mathrm{~mm}$ squares.

Data analysis. A split-plot analysis of variance was used to test the validity of pooling beach seine catches (pollock $100 \mathrm{~m}^{-2}$ ) among the 4 sample sites. In the ANOVA model, the sample site estimates (subplot factor) are free from variation due to seasonal effects (main plot factor) and these were replicated over $2 \mathrm{yr}$ (Littell et al. 1991, Winer et al. 1991). The choice of 2 levels, May + June vs July + August, provided limited seasonal resolution but was dictated by sample size.
Two-factor ANOVAs tested for differences in pollock densities among the 6 tidal stages and the 2 habitats for each of 4 combinations of season and diel period. Tukey's test was used for multiple comparisons among the tidal stages. Analysis of covariance was used to remove the variation due to differences in pollock body weights from the analysis of their stomach content weights. A 2 -factor model compared stomach weights for tide direction and diel period.

All analyses used the general linear models (GLM) procedures in SAS (SAS Institute 1988). All variables were $\log _{e}$-transformed to normalize distributions and to reduce the heteroscedascity in variance. All means are presented with their standard errors.

\section{RESULTS}

\section{Pollock distribution}

Densities in the shallow intertidal zone were not significantly different between years and sites but there were seasonal differences (Table 1). For subsequent analyses of pollock densities the data were combined over the 4 sites and 2 years. Overall, average densities declined from a mean of $2.72 \pm 0.47$ fish haul $^{-1}$ in early summer to a mean of $0.26 \pm 0.04$ fish haul $^{-1}$ in late summer There was a large diel difference in the magnitude of the seasonal decline. During the day, densities declined by 27 times from a mean of $1.44 \pm$ 0.41 fish haul $^{-1}$ in early summer to $0.05 \pm 0.02$ fish haul $^{-1}$ in late summer. At night, densities were much higher than during the day but declined by only 6 times from a mean of $6.34 \pm 1.33 \mathrm{fish} \mathrm{haul}^{-1}$ in early summer to $1.05 \pm 0.15$ fish haul $^{-1}$ in late summer

In early summer during the day, tidal effects on pollock densities were highly significant $(p=0.0001$; Table 2). Densities were higher ( 1.35 to 3.74 fish haul $^{-1}$ ) in the 3 lowest tidal stages and much lower $(0.09$ to 0.73 fish haul ${ }^{-1}$ ) in the 3 highest tidal stages (Fig. 2a). In late summer, diurnal catches were much lower $(<0.3$ fish haul $\left.^{-1}\right)$ and the tidal stage effect was not significant $(\mathrm{p}=$ 0.2543). However, the overall trends appeared similar,

Table 1. Pollachius virens. Results of split-plot analysis of variance comparing $\log _{e}$-transformed number of age $0+$ pollock captured per seine haul among years, seasons and sites

\begin{tabular}{|lcrrc|}
\hline Source of variation & df & SS & $F$ & p \\
\hline Year & 1 & 0.55 & 1.35 & 0.2462 \\
Season & 1 & 41.11 & 99.48 & 0.0001 \\
Year $\times$ Season & 1 & 1.49 & 3.61 & 0.0575 \\
Site & 3 & 1.25 & 1.01 & 0.3873 \\
Season $\times$ Site & 3 & 0.54 & 0.43 & 0.7295 \\
\hline
\end{tabular}


Table 2. Pollachius virens. Results of 2-way ANOVA of $\log _{e}-$ transformed number of age $0+$ pollock captured per seine haul among tidal stages and habitats. Comparisons were made for both early and late summer during day and night

\begin{tabular}{|c|c|c|c|c|}
\hline Source of variation & $d f$ & SS & F & $\mathrm{p}$ \\
\hline \multicolumn{5}{|l|}{ Early summer day } \\
\hline Tidal stage & 5 & 22.85 & 10.38 & 0.0001 \\
\hline Habitat & 1 & 0.71 & 1.61 & 0.2046 \\
\hline Tide $\times$ Habitat & 4 & 2.07 & 1.17 & 0.3216 \\
\hline \multicolumn{5}{|l|}{ Late summer day } \\
\hline Tidal stage & 5 & 0.18 & 1.32 & 0.2543 \\
\hline Habitat & 1 & 0.01 & 0.51 & 0.4745 \\
\hline Tide $\times$ Habitat & 4 & 0.26 & 1.92 & 0.0889 \\
\hline \multicolumn{5}{|l|}{ Early summer night } \\
\hline Tidal stage & 5 & 57.14 & 11.60 & 0.0001 \\
\hline Habitat & 1 & 0.31 & 0.25 & 0.6160 \\
\hline Tide $\times$ Habitat & 4 & 1.85 & 0.50 & 0.6815 \\
\hline \multicolumn{5}{|l|}{ Late summer night } \\
\hline Tidal stage & 5 & 4.77 & 2.48 & 0.0334 \\
\hline Habitat & 1 & 0.71 & 1.86 & 0.1747 \\
\hline Tide $\times$ Habitat & 4 & 2.10 & 1.82 & 0.1456 \\
\hline
\end{tabular}

except that catches during the low-falling tide were more similar to high-tide than to low-tide patterns (Fig. 2b). In early summer during the night, the pattern of catches was similar to the pattern during the day, ex- cept that catches were very small in the low-rising period (Fig. 3a). In late summer at night, when the tidal stage differences were significant ( $p=0.0334)$, but only marginally, the trend for highest catches on the low tides was weak (Fig. 3b). During this period the catches on the high-rising and high-falling tides were comparable to those on the low-rising and low-falling tides, respectively. There was also a trend towards overall higher catches on the falling than rising tides.

\section{Pollock diet}

The frequencies of occurrence of major prey groups in pollock stomachs (Table 3 ) indicate that crustaceans from algal habitats were the most widely consumed prey type in early summer. Harpacticoid copepod species that are characteristic of algal habitats occurred in $91.5 \%$ of the fish while calanoid copepods, the most frequently occurring pelagic prey, were found in $38.8 \%$ of the fish. Prey from benthic sedimentary habitats were rare (less than $5 \%$ of stomachs). From early to late summer the occurrence of both copepod groups dropped by more than half while that of chironomid larvae and the snail Littorina obtusata, both characteristic of algal habitats, increased. Pelagic habitat prey

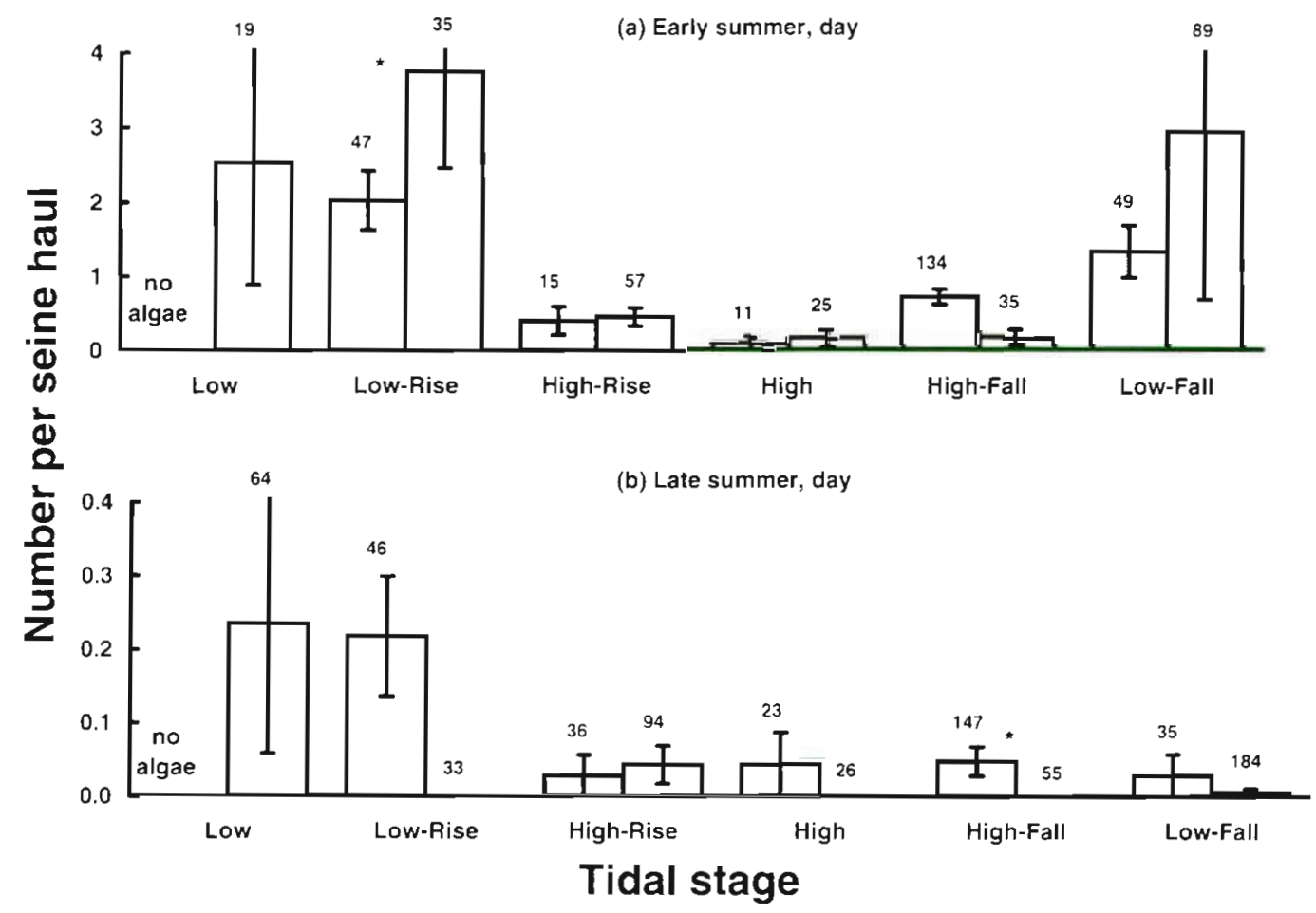

Fig. 2. Pollachius virens. Mean number of age $0+$ pollock per seine haul in the shallow intertidal zone at 6 stages of the tide during the day in (a) early summer and (b) late summer Shaded and open bars represent the algal and open habitat, respectively. Number of seine haul samples is indicated above each bar 'Significant difference between habitat types (Bonferroni $t$-test, $\mathrm{p}<0.05$ ). Vertical lines are standard errors 


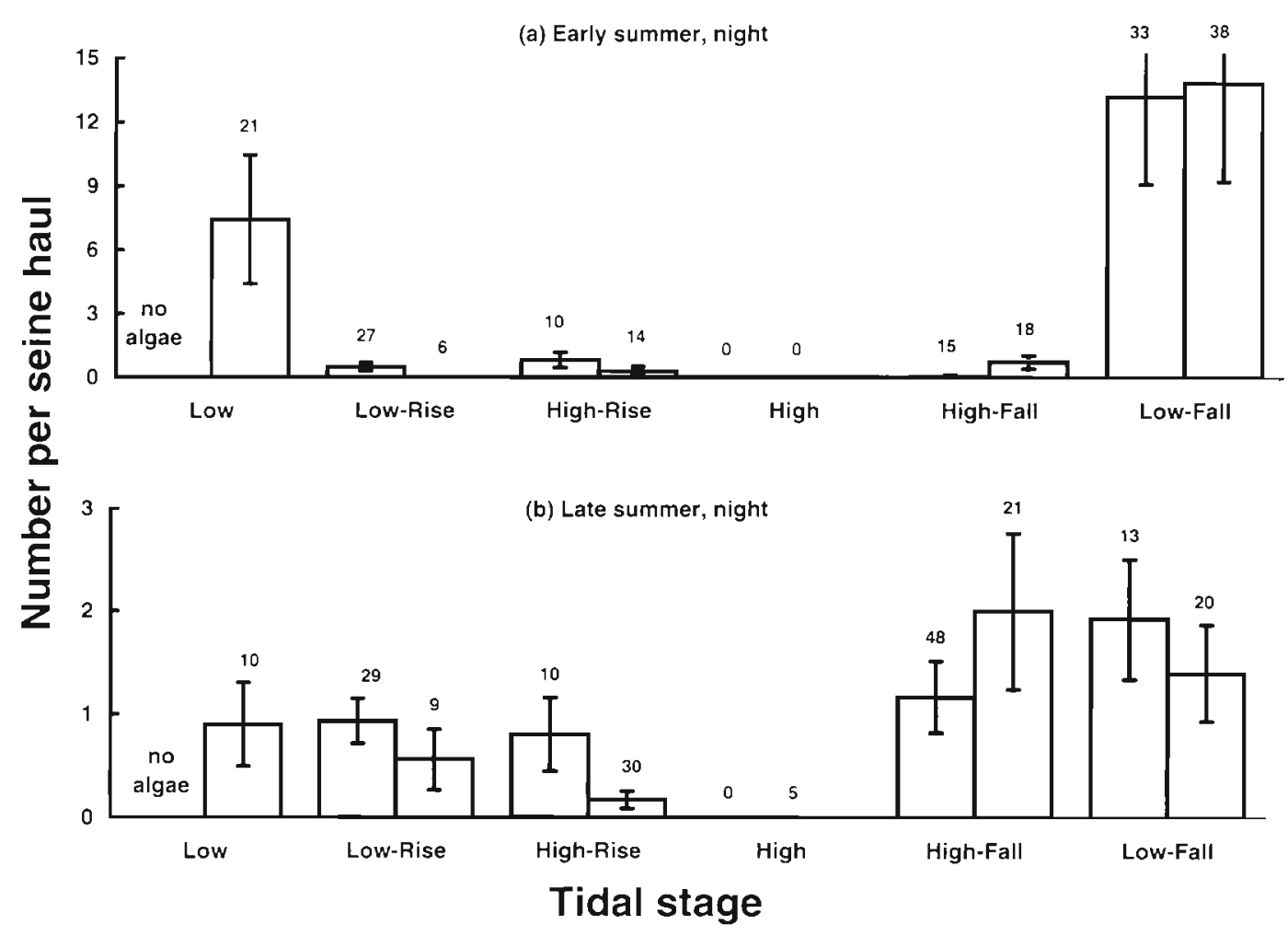

Fig. 3. Pollachius virens. Mean number of age 0+ pollock per seine haul at night in (a) early summer and (b) late summer. Shaded and open bars represent the algal and open habitat, respectively. Number of seine haul samples is indicated above each bar. Differences between habitat types were not significant (Bonferroni $t$-test, $\mathrm{p}>0.05$ ). Vertical lines are standard errors

decreased overall while benthic habitat prey increased to about $10 \%$ and included mussel spat Mytilus edulis, isopods and amphipods. During this same period, mean pollock fork lengths increased from $4.9 \pm 0.06 \mathrm{~cm}$ in early summer to $8.7 \pm 0.10 \mathrm{~cm}$ in late summer.

The mean number of prey items and the relative volume of prey from different habitats are presented in Table 4. Prey from algal habitats dominated the diets both in prey number and volume. The mean number of prey from algal habitats decreased from early to late summer, probably reflecting the shift to fewer but larger-sized prey (e.g. fewer copepods and more amphipods) as percent volume only dropped slightly. At the same time, the mean number of prey from the pelagic habitat nearly doubled, while the volume decreased slightly. Numerically and by volume, benthic prey were a minor component of pollock diets throughout the summer.

Tide direction (rise vs fall) and diel period (day vs night) both had significant effects on the fullness of pollock stomachs (Table 5). The weight of stomach contents, relative to body weight, was greater during the day than at night in early summer $(\bar{x}=4.06 \pm 0.13 \%$ vs $\bar{x}=3.56 \pm 0.16 \%)$ and in late summer $(\bar{x}=3.45 \pm$ $0.32 \%$ vs $\bar{x}=3.11 \pm 0.15 \%$ ). The relative weight of stomach contents was greater on the rising tide than on the falling tide $(\bar{x}=4.14 \pm 0.17 \%$ vs $\bar{x}=3.75 \pm 0.12 \%)$ in early summer while in late summer the relative weight of stomach contents was greater on the falling tide than on the rising tide $(\bar{x}=3.63 \pm 0.19 \%$ vs $\bar{x}=2.64$ $\pm 0.16 \%$ ).

\section{DISCUSSION}

\section{Intertidal zone migration}

Juvenile pollock were present in the shallow intertidal zone at all stages of the tide, day and night throughout the summer. Our findings that pollock were in shallow water at the high tidal stages indicate that at least part of the pollock population migrated across the full width of the shore each tide, a distance of approximately $150 \mathrm{~m}$. The presence of juvenile pollock in the intertidal zone is well known (e.g. Bertelsen 1942, Lie 1961, MacDonald et al. 1984, Black \& Miller 1991, Ojeda \& Dearborn 1991) but, prior to our study, there have been no detailed investigations of tidal migrations and habitat use by pollock and few on other fishes in the rocky intertidal zone (Gibson 1982, Ralston \& Horn 1986, Rangeley 1994a). These include observations of cunner Tautogolabrus adspersus for- 
Table 3. Pollachius virens. Percent frequency of occurrence of the major prey groups from stomachs of juvenile pollock for both early $(n=448)$ and late $(n=176)$ summer

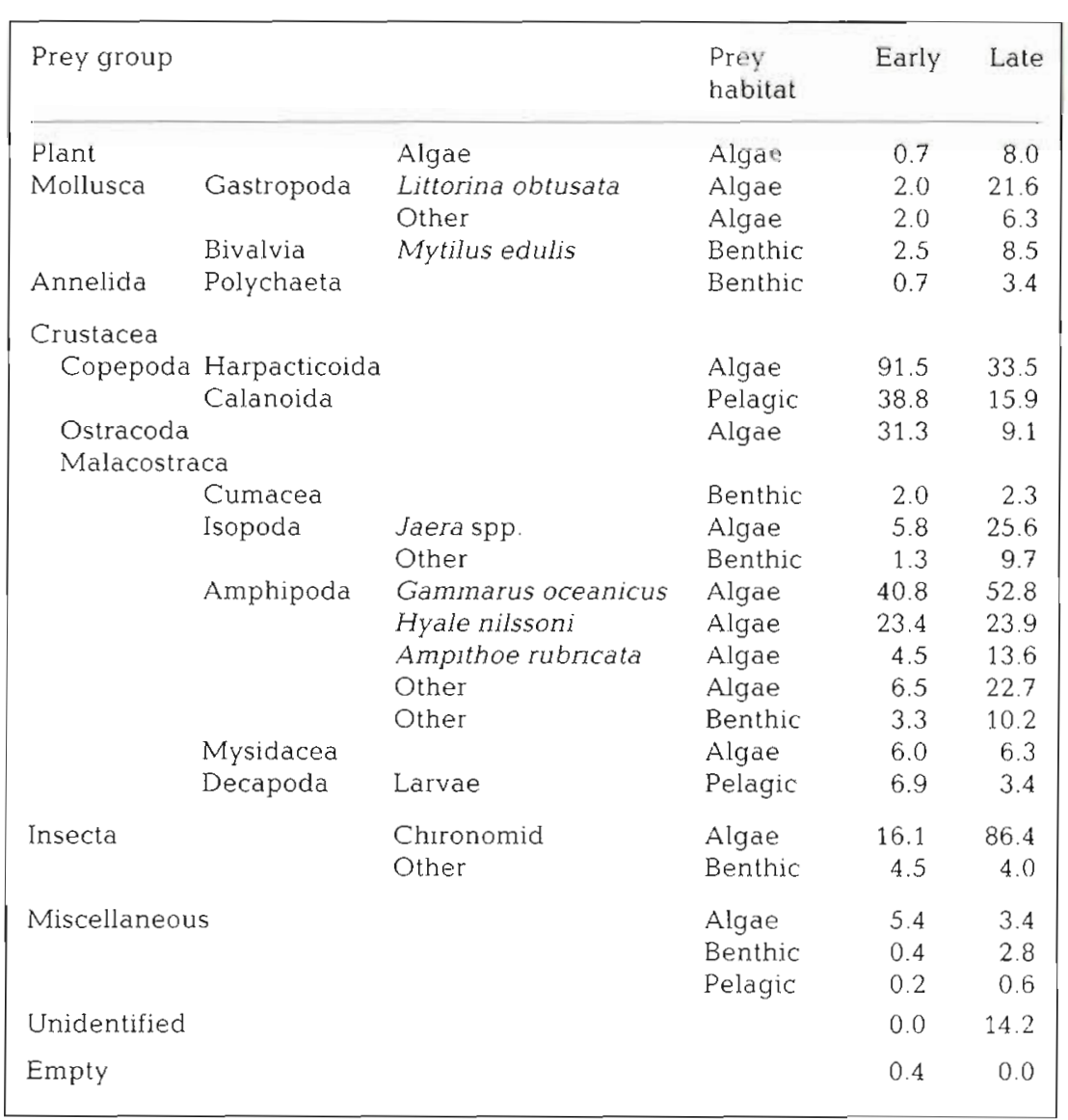

delayed entry into the intertidal zone on the rising tide and that pollock had either dispersed at the high tidal stages or remained in the low zone throughout the tidal cycle. These diel patterns reflect active rather than passive movement with the tides. In late summer, the tidal migration patterns were not as strong as in early summer. The differences in pollock catches between low and high tidal stages were marginal at night and not significant during the day.

Numerous studies have reported higher nocturnal densities of fishes in shallow waters. For example, catches of inshore fishes, including age $0+$ and $1+$ pollock, in the UK were 2 to 29 times higher at night (Kruuk et al. 1988). Juvenile cod Gadus morhua densities increased 16 -fold in shallow water at night compared to day estimates (Keats 1990; see also Methven \& Bajdik 1994). Bertelsen (1942) and Lie (1961) reported greater catches of juvenile pollock at night, as did Nagabhushanam (1965) for gadids generally. It seems likely that diel shifts in distribution patterns may be widespread although changes

aging from intertidal boulder refuges at high tide (Whoriskey 1983) and the herbivorous foraging of Cebidichthys violaceus in the rocky mid-intertidal zone during flood tides (Ralston \& Horn 1986). The only other detailed investigation of fish migrations into the rocky intertidal zone is our companion study of pollock based on observations from underwater transects (Rangeley \& Kramer 1995, this issue). In contrast, there are many studies of fish migrations into intertidal habitats in other systems (e.g. Tyler 1971, Gibson 1973 , Wirjoatmodjo \& Pitcher 1984, McIvor \& Odum 1988, Sogard et al. 1989, Ansell \& Gibson 1990, Levings et al. 1991, Kneib \& Wagner 1994).

There was a clear tidal pattern to the intertidal zone distribution of pollock. Captures were much higher at low than at high tidal stages in early summer, suggesting that during the day there was an initial high density influx on the low-rising tide followed by dispersal over the high tidal stages and a subsequent concentration of fish during the low-falling tide. This pattern is inconsistent with pollock moving with the tides as a front following a particular water depth. The somewhat different pattern of captures at night suggests a in catchability may be a potential source of bias. We are not aware of any experimental assessment of diel effects on beach seine efficiency. Studies using other gear types have shown that diel changes in both distribution patterns and catchability can affect fish density estimates (Allen \& DeMartini 1983, Gliwicz \& Jachner 1992).

Table 4. Pollachius virens. Mean number ( \pm SE) of pollock prey and the mean percentage $( \pm S E)$ of prey, by volume, from each habitat type for both early and late summer

\begin{tabular}{|lrr|}
\hline Habitat & Prey number & $\%$ vol of prey \\
\hline Early summer & $118.0(5.9)$ & $89.1(1.0)$ \\
Algal & $13.5(1.7)$ & $8.9(0.9)$ \\
Pelagic & $1.2(0.4)$ & $1.8(0.5)$ \\
Benthic & 0.0 & 0.0 \\
Unidentified & & \\
Late summer & $82.5(8.4)$ & $80.4(2.4)$ \\
Algal & $25.2(6.7)$ & $7.9(1.7)$ \\
Pelagic & $2.8(0.9)$ & $4.7(1.2)$ \\
Benthic & 0.0 & $7.0(1.5)$ \\
Unidentified & & \\
\hline
\end{tabular}


Table 5. Pollachius virens. Analysis of covariance of the $\log _{e}$ weight of pollock stomach contents with $\log _{e}$ body weight as the covariate. Comparisons were made among tide directions (rise vs fall) and diel periods (day vs night) for both early and late summer

\begin{tabular}{|lrrr|}
\hline Source of variation & SS & $F$ & \multicolumn{1}{c|}{$\mathrm{p}$} \\
\hline Early summer & & & \\
Body weight & 3.90 & 1113.30 & 0.0001 \\
Tide direction & 0.13 & 4.52 & 0.0341 \\
Diel period & 0.46 & 16.67 & 0.0001 \\
Tide $\times$ Diel & 0.00 & 0.15 & 0.6955 \\
Late summer & & & \\
Body weight & 13.92 & 132.84 & 0.0001 \\
Tide direction & 0.59 & 5.65 & 0.0186 \\
Diel period & 0.43 & 4.15 & 0.0432 \\
Tide $\times$ Diel & 0.11 & 1.06 & 0.3043 \\
\hline
\end{tabular}

Pollock catches were not significantly different between algal and open habitats in most comparisons. However, any conclusions about pollock habitat use must take into account the tidal changes in relative habitat availability. Approximate estimates of relative habitat availability in Brandy Cove, New Brunswick (see Rangeley \& Kramer 1995), ranged from no macroalgae at low tide to 4 times as much algae on the high tide (Rangeley \& Kramer unpubl.). The 4 beach seine sites in this study were qualitatively similar in the relative increase in algal cover with tide height. Since pollock densities differed little between habitats and algal area increased, it seems likely that the abundance of pollock in the algal habitat increased with tide height. In addition, while pollock clearly used the open habitat in the heterogeneous rocky intertidal zone of this study, they are known to be rare or absent in much larger-scale open habitats comprising intertidal zone sand and mud flats (e.g. Steele 1963, Tyler 1971, Gibson 1973).

There was an order of magnitude decline in pollock catches from early to late summer. Seasonal declines in juvenile pollock densities have also been observed in other studies. Pollock seined during low tide declined approximately $90 \%$ from early to late summer (MacDonald et al. 1984). Relative densities of seined pollock in the intertidal zone declined by $50 \%$ one month after settlement in the Faroe Islands (Bertelsen 1942). In contrast, Black \& Miller (1991) observed a seasonal increase of juvenile pollock captures using fixed seines in Nova Scotia, Canada. However, they used a net mesh size incapable of retaining age $0+$ pollock in early summer, resulting in catches consisting of age $1+$ in early summer and a mix of age classes in late summer after the age 0+ grew to a catchable size. Predation is likely a more important cause of the seasonal decline in pollock density than emigration. This is because pollock movements in the summer are directed on and off the intertidal zone rather than along the shoreline, suggesting high site fidelity (Rangeley \& Kramer 1995). There is also evidence that predation risk may be high from 7 species of piscivorous birds foraging widely among all depths, habitats and tidal stages (Rangeley 1994b).

\section{Pollock foraging}

Pollock appeared to have foraged relatively continuously. There were only relatively small tide-direction and diel differences in the weight of pollock stomach contents. Also, stomachs were rarely empty and most prey were intact and easily identified, suggesting that they were recently consumed. Empty stomachs were also rare in pollock sampled by beach seine on European shores (Lie 1961, Mironova 1961). Our data indicate that pollock were foraging both day and night. This is not surprising considering they are capable of visual feeding in low light and that many of their crustacean prey are nocturnally active (Woodhead 1966. Westin \& Aneer 1987).

The diets of juvenile pollock were dominated by prey originating in the algal habitat of the rocky intertidal zone. The principal dietary items were crustaceans, especially harpacticoid and calanoid copepods, isopods and amphipods; also important were chironomid larvae and small gastropods. Of these prey groups, all included species typically found closely associated with algae, except for the calanoid copepods, which are pelagic. Benthic prey were rare in pollock diets. There was a seasonal shift in the composition of pollock diets. From early to late summer their diets changed from consisting of many small prey to fewer larger prey. These dietary changes reflect a decrease in copepods and ostracods and an increase in isopods, amphipods, chironomids and small gastropods. At the same time the relative contribution of pelagic and benthic prey increased slightly. Foraging migrations into tidal freshwater and salt marshes (Kneib 1984, 1987, Mclvor \& Odum 1988, Rozas \& Odum 1988, Levings et al. 1991), in non-fucoid macroalgal habitats and in seagrass beds (Olney \& Boehlert 1988, Sogard 1992) are beneficial to juvenile fishes because of high invertebrate prey densities relative to open habitats. There are no studies which have compared prey availability among rocky shore habitats. However, it seems likely that algae is also a profitable foraging habitat given the high abundance and diversity of invertebrates found there (e.g. Lewis 1964, Thomas et al. 1983) and the high growth rates of juvenile pollock compared with other gadids (Mironova 1961, Steele 1963, Scott \& Scott 1988, Clay et al. 1989).

This study detailed patterns of tidal migration and foraging by a juvenile fish in the rocky intertidal zone. 
With the exception of Rangeley \& Kramer (1995), there is a paucity of information about fishes, other than those which reside in tide pools, in the rocky intertidal zone. Rockweed algae is used for foraging and possibly as a refuge from predators which strongly suggests this habitat is an important fish nursery. This has important implications for coastal habitat management. For example, reduced algal biomass and canopy height due to commercial harvesting of rockweed algae (Rangeley 1994a) may seriously impact fish using the rocky intertidal zone.

Acknowledgements. We thank the staff of the Huntsman Marine Science: Centre (HMSC) and the Canadian Department of Fisheries \& Oceans (DFO) in St. Andrews for much assistance and the use of facilities. Excellent field and laboratory assistance was provided by Blair Cooper, Jacky Farrell, Gary Gratto, Arne Mooers and John Wecherkiwsky. Thanks to Drs D. F. Bertram, R. C. Chambers, D. Fairbairn, W. Hunte, W. C. Leggett, J. D. Neilson, J. B. Rasmussen, D. Roff, K. D. E. Stokesbury, E. A. Trippel and Ms M. J. Rudi and 2 anonymous reviewers for comments which greatly improved earlier versions of this paper. R.W.R. is grateful for financial support from HMSC and Fonds pour la Formation de Chercheurs FCAR (Quebec). The research was funded from a Natural Sciences and Engineering Research Council of Canada (NSERC) operating grant and 2 DFO/NSERC subvention grants awarded to D.L.K.

\section{LITERATURE CITED}

Allen LG, DeMartini EE (1983) Temporal and spatial patterns of nearshore distribution and abundance of the pelagic fishes off San Onofre-Oceanside, California. Fish Bull 81 569-586

Ansell AD, Gibson RN (1990) Patterns of feeding and movement of juvenile flatfishes on an open sandy beach. In Barnes M, Gibson RN (eds) Trophic relationships in the marine environment. Aberdeen University Press, Aberdeen, p 191-207

Bertelsen E (1942) Contributions to the biology of the coalfish (Gadus virens L.) in Faroe waters. Meddr Kommn Danm Fisk og Havunders (Ser Fiskeri) 11:1-68

Bigelow HB, Schroeder WC (1953) Fishes of the Gulf of Maine. US Fish and Wildlife Service, Washington

Black R, Miller RJ (1991) Use of the intertidal zone by fish in Nova Scotia. Environ Biol Fish 31:109-121

Bousfield EL (1973) Shallow-water gammaridean Amphipoda of New England. Comstock Publishing Associates, Ithaca, NY

Briand X (1991) Seaweed harvesting in Europe. In: Guiry MD, Blunden $G$ (eds) Seaweed resources in Europe: uses and potential. John Wiley \& Sons Ltd, New York, p 259-308

Brinkhurst RO, Linkletter LE, Lord EI, Connors SA, Dadswell MJ (1975) A preliminary guide to the littoral and sublittoral marine invertebrates of Passamaquoddy Bay. Huntsman Marine Laboratory, St Andrews, NB

Cheng L (1976) Marine insects. North-Holland Publishing Co, Amsterdam

Clay D, Stobo WT, Beck B. Hurley PCF (1989) Growth of juvenile pollock (Pollachius virens L.) along the Atlantic coast of Canada with inferences of inshore-offshore movements. J Northwest Atl Fish Sci 9:37-43
Coffman WP, Ferrington LC (1984) Chironomidae. In Merritt RW, Cummins KW (eds) An introduction to the aquatic insects of North America. Kendall/Hunt, Dubuque, p 551-652

Fahay MP (1983) Guide to the early stages of marine fishes occurring in the western North Atlantic Ocean, Cape Hatteras to the southern Scotian shelf. J Northwest Atl Fish Scj 4:1-423

Gibson RN (1973) The intertidal movements and distribution of young fish on a sandy beach with special reference to the plaice (Pleuronectes platessa L.). J exp mar Biol Ecol 12:79-102

Gibson RN (1982) Recent studies on the biology of intertidal fishes. Oceanogr mar Biol A Rev 20:363-414

Gibson RN (1986) Intertidal teleosts: life in a fluctuating environment. In: Pitcher $\mathrm{TJ}$ (ed) The behaviour of teleost fishes. Croom Helm, London, p 388-408

Gilwicz ZM, Jachner A (1992) Diel migrations of juvenile fish: a ghost of predation past or present? Arch Hydrobiol $124: 385-410$

Gosner KL (1971) Guide to identification of marine and estuarine invertebrates. Wiley-Interscience Inc, New York

Hayward PJ (1980) Invertebrate epiphytes of coastal marine algae. In: Price JH, Irvine DEG, Farnham WF (eds) The shore environment, Vol 2, Ecosystems. Academic Press, New York, p 761-787

Heck KL, Crowder LB (1991) Habitat structure and predatorprey interactions in vegetated systems. In: Bell SS, McCoy ED. Mushinsky HR (eds) Habitat structure: the physical arrangement of objects in space. Chapman \& Hall, New York, p 281-299

Holbrook SJ, Schmitt RJ (1988) The combined effects of predation risk and food reward on patch selection. Ecology 69:125-134

Keats DW (1990) A nocturnal inshore movement of juvenile cod Gadus morhua L. in eastern Newfoundland. J exp mar Biol Ecol 139:167-173

Keser M, Vadas RL, Larson BR (1981) Regrowth of Ascophyllum nodosum and Fucus vesiculosus under various harvesting regimes in Maine, U.S.A. Botanica mar 24:29-38

Kneib RT (1984) Patterns in the utilization of the intertidal salt marsh by larvae and juveniles of Fundulus heteroclitus (Limnaeus) and Fundulus luciae (Baird). J exp mar Biol Ecol 83:41-51

Kneib RT (1987) Predation risk and use of intertidal habitats by young fishes and shrimp. Ecology 68:379-386

Kneib RT, Wagner SL (1994) Nekton use of vegetated marsh habitats at different stages of tidal inundation. Mar Ecol Prog Ser 106:227-238

Kruuk H, Nolet B. French D (1988) Fluctuations in numbers and activity of inshore demersal fishes in Shetland. J mar biol Ass UK 68:601-617

Levings CD, Conlin K, Raymond B (1991) Intertidal habitats used by juvenile chinook salmon (Oncorhynchus tshawytscha) rearing in the north arm of the Fraser River Estuary. Mar Pollut Bull 22:20-26

Lewis JR (1964) The ecology of rocky shores. The English Universities Press Ltd, London

Lie U (1961) On the growth and food of 0-group coalfish, Pollachius virens (L.), in Norwegian waters. Sarsia 3:1-36

Linkletter LE, Lord EI, Dadswell MJ (1977) A checklist of marine fauna and flora of the Bay of Fundy. Huntsman Marine Laboratory, St Andrews, NB

Littell RC, Freund RJ, Spector PC (1991) SAS system for linear models. SAS Institute Inc, Cary, NC

MacDonald JS, Dadswell MJ, Appy RG, Melvin GD, Methven DA (1984) Fishes, fish assemblages, and their seasonal 
movements in the lower Bay of Fundy and Passamaquoddy Bay, Canada. Fish Bull 82:121-139

Marak RR, Colton JB (1961) Distribution of fish eggs and larvae, temperature, and salinity in the Georges Bank Gulf of Maine area, 1953. US Fish Wildlife Serv, Spec Sci Rep 398:1-61

Markle DF, Frost LA (1985) Comparatıve morphology, seasonality, and a key to planktonic fish eggs from the Nova Scotian shelf. Can J Zool 63:246-257

Mayo RK, McGlade JM, Clark SH (1989) Patterns of exploitation and biological status of pollock (Pollachius virens $\mathrm{L}$.) in the Scotian shelf, Georges Bank, and Gulf of Maine area. J Northwest Atl Fish Sci 9:13-36

McIvor CC, Odum WE (1988) Food, predation risk, and microhabitat selection in a marsh fish assemblage. Ecology 69: $1341-1351$

Methven DA, Bajdik C (1994) Temporal variation in size and abundance of juvenile atlantic cod (Gadus morhua) at an inshore site off eastern Newfoundland. Can J Fish Aquat Sci 51:78-90

Mironova NV (1961) Biology of the Barents Sea saithe, Pollachius virens (L.). Int Rev ges Hydrobiol 46:447-459

Moring JR (1990) Seasonal absence of fishes in tidepools of a boreal environment (Maine, USA). Hydrobiologia 194: $163-168$

Nagabhushanam AK (1965) On the biology of the commoner gadoids in Manx waters. $J$ mar biol Ass UK 45:615-657

Ojeda FP, Dearborn JH (1991) Feeding ecology of benthic mobile predators: experimental analyses of their influence in rocky subtidal communities of the Gulf of Maine. J exp mar Biol Ecol 149:13-44

Olney JE, Boehlert CW (1988) Nearshore ichthyoplankton associated with seagrass beds in the lower Chesapeake Bay. Mar Ecol Prog Ser 45:33-43

Ralston SL, Horn MH (1986) High tide movements of the temperate-zone herbivorous fish Cebidichthys violaceus (Girard) as determined by ultrasonic telemetry. J exp mar Biol Ecol 98:35-50

Rangeley RW (1994a) The effects of seaweed harvesting on fishes - a critique. Environ Biol Fish 39:319-323

Rangeley RW (1994b) Habitat selection in juvenile pollock, Pollachius virens: behavioural responses to changing habitat availability. PhD thesis, McGill University, Montreal

Rangeley RW, Kramer DL (1995) Tidal effects on habitat selection and aggregation by juvenile pollock Pollachius virens in the rocky intertidal zone. Mar Ecol Prog Ser $126: 19-29$

Rozas LP, Odum WE (1988) Occupation of submerged aquatic

This article was submitted to the editor vegetation by fishes: testing the roles of food and refuge Oecologia 77:101-106

Sars GO (1890) An account of the Crustacea of Norway. Universitetsforlaget, Bergen

SAS Institute (1988) SAS/STAT user's guide, release 6.03 edn SAS Institute Inc, Cary, NC

Scott WB, Scott MG (1988) Atlantic fishes of Canada. Can Bull Fish Aquat Sci 219:1-731

Smith DL (1977) A guide to marine coastal plankton and marine invertebrate larvae. Kendall/Hunt Publishing $\mathrm{Co}$ Dubuque

Sogard SM (1992) Variability in growth rates of juvenile fishes in different estuanne habitats. Mar Ecol Prog Ser 85:35-53

Sogard SM, Powell GVN, Holmquist JG (1989) Utilization by fishes of shallow, seagrass-covered banks in Florida Bay 2. Diel and tidal patterns. Environ Biol Fish 24:81-92

Steele DH (1963) Pollock Pollachius virens (L.) in the Bay of Fundy. J Fish Res Bd Can 20:1267-1314

Thomas MLH, Arnold DC, Taylor ARA (1983) Rocky intertidal communities. In: Thomas MLH (ed) Marine and coastal systems of the Quoddy region, New Brunswick. Can Spec Publ Fish Aquat Sci, p 35-73

Trites RW, Garrett CJ (1983) Physical oceanography of the Quoddy region. In: Thomas MLH (ed) Marine and coastal systems of the Quoddy region, New Brunswick. Can Spec Publ Fish Aquat Sci, p 9-34

Tyler AV (1971) Surges of winter flounder, Pseudopleuronectes americanus, into the intertidal zone. J Fish Res Bd Can 28:1727-1732

Vadas RL, Wright WA, Miller SL (1990) Recruitment of Ascophyllum nodosum: wave action as a source of mortality. Mar Ecol Prog Ser 61:263-272

Westin L, Aneer G (1987) Locomotor activity patterns of nineteen fish and five crustacean species from the Baltic Sea. Environ Biol Fish 20:49-65

Wheeler A (1980) Fish-algal relations in temperate waters. In: Price $\mathrm{JH}$, Irvine DEG, Farnham WF (eds) The shore environment, Vol 2, Ecosystems. Academic Press, New York, p $677-698$

Whoriskey FG (1983) Intertidal feeding and refuging by cunners, Tautogolabrus adspersus (Labridae). Fish Bull 81: $426-428$

Winer BJ, Brown DR, Michels KM (1991) Statistical principles in experimental design. McGraw-Hill, Inc, New York

Wirjoatmodjo S, Pitcher TJ (1984) Flounders follow the tides to feed: evidence from ultrasonic tracking in an estuary. Estuar coast Shelf Sci 19:231-241

Woodhead PMJ (1966) The behaviour of fish in relation to light in the sea. Oceanogr mar Biol A. Rev 4:337-403

Manuscript first received: August 19, 1994

Revised version accepted: April 3, 1995 